\title{
TEOLOGIA NAWRÓCENIA W KSIĘDZE PROROKA JEREMIASZA
}

Temat nawrócenia w Księdze proroka Jeremiasza jest dziś bardzo aktualny i to z podwójnej racji. Najpierw z powodu ogólnego zainteresowania teologicznego tematyką pokuty i nawrócenia, co znalazło swój wyraz w obradach synodu biskupów w r. 1983. Po wtóre, obserwuje się dzisiaj wzrost zainteresowania postacią i teologią proroka Jeremiasza, o czym może świadczyć poświęcenie tej właśnie problematyce całej sesji Journées Bibliques w Louvain w 1980 r. ${ }^{1}$ Mimo owego zainteresowania tematyką pokuty, bibliografia naukowa na ten temat nie jest wcale obszerna, a jeżeli chodzi o Jeremiaszową koncepcję nawrócenia, to nie ma dotąd żadnego pracowania monograficznego. Wprawdzie w niektórych bibliografiach spotyka się artykuł G. Fohrera: Umkehr und Erlösung beim Propheten Heremia ${ }^{2}$, ale jest to pomyłka, ponieważ prawdziwy tytuł tego artykułu brzmi: Umkehr und Erlösung beim Propheten Hosea ${ }^{3}$ i rzeczywiście ten temat autor w nim omawia. Jest to poważna luka bibliograficzna $\mathrm{z}$ tego powodu, że jeden $\mathrm{z}$ ostatnich proroków Izraela Zachariasz, podsumowując działalnọść swoich profetycznych poprzedników, scharakteryzował ją jako nawoływanie do nawrócenia $(1,4)$, a przecież prorok z Anatot wniósł największy wkład w rozwój tej idei w Starym Testamencie i dlatego słusznie nadaje mu się tytuł „doktora nawrócenia”. Prorok u Anatot, podobnie jak inni prorocy-pisarze oraz autorzy pozostałych ksiąg Starego Testamentu, wyraża powrót grzesznych ludzi do Boga przy pomocy szeregu zwrotów zaczerpniętych z języka obiegowego np. „poznać Jahwe (jādă JHWH), szukać Jahwe (biqqeš JHWH), pytać o Jahwe (dāraš JHWH). Wyrażeń tych używa jednak rzadko w stosunku do słowa šûb, którym posługuje się aż 112 razy, a więc najczęściej ze wszystkich autorów Ksiąg Starego Testamentu. Słowem tym w bogatej religijnej gamie znaczeniowej określa cały proces odejścia Izraela od Boga, stan buntu przeciw Niemu, a przede wszystkim cały proces nawrócenia, na który składa się odwrócenie od zła i powrót do $\mathrm{Boga}^{4}$.

${ }^{1}$ Le livre de Jérémie. Le prophète et son milieu. Les oracles et leur transmission (BETL 54), red. P. - M. Bog a ert, Leuven 1981.

${ }^{2}$ Np. J. Fichter, Bekehrung im AT, RGG ${ }^{3}$ I, s. 978. M. Goł ę biow s ki, Pokuta w Starym Testamencie, AK 89(1977), s. 8(odn. 11).

${ }^{3}$ ThZ 11(1955), s. 161-185.

${ }^{4}$ Obszerne opracowanie na ten temat w mojej rozprawie doktorskiej: Zagadnienie nawrócenia w Księdze Proroka Jeremiasza. Studium egzegetyczno-teologiczne, Kraków 1983, s. 11-70(Biblioteka PAT w Krakowie). 
Teologię nawrócenia Księgi Jeremiasza ująłem w trzy punkty. Wstępne kroki Izraela w procesie nawrócenia, czyli zachowanie moralno-religijne, jakiego koniecznie domagał się Jeremiasz, wzywając na drogę powrotu do Boga, będą treścią pierwszego punktu. W drugim punkcie przedstawię istotne cechy charakteryzujące samo nawrócenie u proroka z Anatot. W ostatnim zaś punkcie ukażę, jak widział Jeremiasz Bożą ingerencję w zapowiedzianym nawróceniu czlowieka.

\section{WARUNKI NAWRÓCENIA IZRAELA}

Powrót Izraelitów do Boga jest możliwy tylko wtedy, gdy spełnią odpowiednie warunki. Prorok Jeremiasz szczególnie wyakcentował sprawę posłuszeństwa narodu słowom proroka, które pochodzą od samego Boga $(37,2)$. Warunek ten można określić jako fundamentalny, ponieważ od jego spełnienia zależy możliwość zrealizowania innych warunków, bez których jest niemożliwy proces nawrócenia. Wtedy tylko Izraelici bowiem mogą do końca zrozumieć okrucieństwo swojego postępowania. Wtedy Izraelici mogą na nowo odkryć urzekającą miłość Jahwe, której nie sposób odrzucić, gdy chociaż trochę się ją pozna. I dzięki temu będą zdolni przeżyć głęboki wstyd i żal z powodu tak grzesznego postępówania, które wyznają Bogu. Dlatego Jeremiasz ustawicznie i niezmordowanie wraca do tego punktu wyjścia w nawróceniu ${ }^{5}$. Jednak już w mowach z pierwszego okresu działalności pytał: „Do kogo mam przemawiać, kogo zaklinać, aby mnie słuchano? Oto nieobrzezane ich ucho więc nie mogą mnie zrozumieć. Oto słowo Jahwe stało się dla nich drwiną, nie mają w nim upodobania" $(6,10)$. Od roku 609 w mowach proroka Bóg szczególnie często wyrzuca Izraelowi zamknięcie się na Jego głos i brak posłuszeństwa: „[...] choć przemawiałem do was ustawicznie i niezmordowanie, nie słuchaliście, a gdy was wzywałem, nie odpowiedzieliście" $(7,13)$.

Do istotnych warunków, od których zależy proces nawrócenia należą: uznanie winy przez Izraela, przekonanie o możliwości powrotu do Boga oparte na doświadczeniu Jego odwiecznej miłości, na dogłębnym przeżyciu Jego miłosierdzia i odczuciu jego wielkości, wreszcie zawstydzenie, żal i wyznanie grzechów. Rozpatrzmy te warunki po kolei.

\section{Uznanie winy przez Izraela}

Aby powrót do Boga mógł się stać faktem, Izrael musi uznać swoją winę: „Uznaj jednak swoją winę, że zdradziłeś Jahwe, Boga twojego" (3,13; por. s. 161.

${ }^{5}$ H. Gross, Umkehr im AT. In der Sicht Propheten Jeremias und Ezechiel ThJB 18(1975), 
14,7.20). Niestety Izrael na to się nie chce zdobyć (2,23.35). Przekonanie o własnej sprawiedliwości i zarozumiałość jest postawą, która najbardziej sprzeciwia się nawróceniu. I dlatego przed Jeremiaszem stanęło trudne zadanie - uświadomienie Judejczykom całego okrucieństwa ich postępowania. Jeremiasz musi w imieniu Boga postawić Judzie straszny zarzut bałwochwalstwa połączonego z prostytucją sakralną $(2,5.8 .11 .20 .23 ; 5,7 ; 7,6.18 .30 ; 11,13.17)$, a niekiedy i z ofiarami z ludzi ku czci Molocha $(7,31 ; 19,4 ; 32,35)$. Nawiązując zaś do Oz 10,1 i Iz 7,1-7; 27,2-5, mówi Jeremiasz, że Izrael ze szczepu szlachetnego poprzez zawarcie Przymierza, zmienił się niestety w szczep zdziczały $(2,23 ; 8,13)$. Postępowanie Izraela wobec Boga jest jednym wielkim aktem niewdzięczności za miłość, jaką obdarzył go Bóg; za tę miłość, która szczególnie przejawiła się w wyprowadzeniu go $\mathrm{z}$ Egiptu i wprowadzeniu do Ziemi Obiecanej $(2,6 ; 3,19 ; 5,7)$. Niewdzięcznego Izraela przypomina narzeczona, która zapomniała o darach narzeczonego (różne ozdoby i wzorzysty pas), a zajęła się szukaniem miłostek $(2,32)$. A przecież Izrael powinien lgnąć do Boga instynktownie w odpowiedzi na okazaną mu miłość $(8,7)$. Zachowanie Izraela jest także nielogiczne i bezsensowne. Od wspaniałego Boga odeszli do nicości (hêbel) i nią się stali $(2,5 ; 10,3-15 ; 16,19 ; 51,18)$. Porzuciwszy prawdziwego Boga odeszli Izraelici do tego, co nie może pomóc (2,11; por. 2,27 n). Postępowanie Izraela przypomina porzucenie jakże cennego w warunkach palestyńskich źródła wody czystej dla marnych cystern i mętnych wód rzek $(2,13$; $17,13)$. Porzucenie Boga przez Izraelitów jest fenomenem jedynym w swym rodzaju, ponieważ nie zdarzyło się ani na Wschodzie, ani na Zachodzie, aby jakiś naród porzucil swych bogów $(2,10)$. Zarzucenie wiary i ufności w Jahwe, by położyć nadzieję w sojuszach jest tragiczne w skutkach także dla jedności i niezawisłości politycznej Izraela $(2,14-18 ; 2,28.36 ; 4,7 ; 27,3)$. Postępowanie Izraela jest haniebne w stosunku do Jahwe $(3,25)$, a jego samego napawa goryczą $(2,19 ; 4,18)$. Z odejściem od Boga poszedł w parze upadek moralny $(5,26-28$; $6,5 \mathrm{n} ; 7,5 \mathrm{n} ; 21,12 ; 22,3.17)$. Jeremiasz nawiązując do starszych tradycji prorockich, akcentujących krzywdy społeczne w Izraelu uznał, że szczególne rozmiary przybrała niesprawiedliwość społeczna $(2,34 ; 5,28 ; 6,7.13 ; 7,6)^{6}$. A zły przykład w tym względzie szedł z góry: król Jojakim zbudował swój pałac „na niesprawiedliwości”, „na bezprawiu”, uciskając lud podatkami i zmuszając do darmowej pracy $(22,13)$. Bogaci Izraelici są twardzi i bezlitośni i dlatego uciskają wdowy, sieroty, przychodniów i ubogich $(5,28 ; 7,6 ; 22,3)$ byle stać się bogatszymi. Ale i w tym względzie przewodził im król Jojakim $(22,17)$. Ponadto szerzy się zdrada, oszustwo i kłamstwo $(9,2-5)$, krzywdzące orzeczenia sądowe $(5,28 ; 7,5 ; 21,12)$, nierząd i cudzołóstwo $(5,7-8 ; 9,1 ; 23,10.14 ; 29,23)$ oraz morderstwo $(2,34 ; 7,6)$.

\footnotetext{
${ }^{6}$ Por. H. D on n e r, Soziale Botschaft der Propheten im Lichte der Gesellschaftsordnung Isra$e l s$, „Oriens Antiquus” 2(1963) s. 229-245.
} 
Aby przekonać Izraelitów o tym, że ich upadek sięga dna, Jeremiasz stosuje wstrząsające porównania stanu religijno-moralnego narodu. Cudzołóstwo Izraelitów, które osiągnęło punkt krytyczny, porównuje Jeremiasz do rozbrykania ogierów szukających bezustannie zaspokojenia huci $(5,8)$. Skłonność Izraelitów do bałwochwalstwa porównuje do żądzy wielbłądzicy i dzikiej oślicy w okresie rui $(2,23 \mathrm{n})$, do niezaspokojonej żądzy zepsutej dziewczyny, która jest opanowana namiętnością do tego stopnia, iż sama wyznaje, że żar jej żądzy domaga się ślepego zaspokojenia $(2,25)$ oraz do skłonności Beduinów arabskich do rabunku $(3,2)$. Postępowanie Izraelitów pod tym względem stoi niżej od otaczających go narodów pogańskich $(2,10 \mathrm{n})$. Wstyd Izraela wskutek okazania się zawiedzionym i śmiesznym ilekroć prosi o pomoc obce bóstwa, przyrównuje prorok do wstydu złodzieja przyłapanego na grzesznym uczynku i przez to zhańbionego $(2,26)$. Nawiązując do proroka Ozeasza $(4,13)$, Jeremiasz mówi Izraelowi smutną prawdę, że przez bałwochwalczy kult z oblubienicy Jahwe zamienił się w nierządnicę $(2,20.23 ; 3,3.20)$ i co tragiczniejsze, w nierządnicę zakłamaną $(3,4 \mathrm{n})$. Do nierządnicy i to gorszej od Królestwa Północnego ze szczególnym naciskiem przyrównuje Jeremiasz Judeę $(3,8.11)$, a źródłem tej nieprawości tryskającym na cały kraj jest stolica — Jerozolima $(6,7)$.

W wykazywaniu winy u Jeremiasza widać pewną ewolucję. W pierwszym etapie swej działalności (626-622) w swym napomnieniu prorockim jest delikatny, wierzy w dobrą wolę ziomków, w możliwość nawrócenia z całego serca. Jednak w miarę upływu lat swej działalności prorockiej zostaje zaskoczony znikomością swojego oddziaływania. Ponadto naród nie okazał się podatny na podwójną reformę Jozjasza. Dlatego też od czasów króla Jojakima używa coraz mocniejszych określeń. Dochodzi aż do tego, że postępowanie fałszywych proroków porównuje do postępowania mieszkańców miast Sodomy i Gomory $(23,14)$ - symboli największego zepsucia moralnego. Zaś ustosunkowanie się Izraelitów do Boga przyrównuje do okrucieństwa dzikich zwierząt gotowych rzucić się na swego największego dobroczyńcę (12,8 n).

\section{Doświadczenie odwiecznej miłości Boga}

Prorok Amos, a później Izajasz, nawołując Izraelitów do nawrócenia, jako dopingujący motyw podjęcia wysiłku gruntownej odnowy życia stawiali widmo strasznych kar Bożych; powrót do Boga miał się dokonać pod presją bojaźni przed karą Bożą. Natomiast prorok Ozeasz chciał wywołać proces nawrócenia Izraelitów, pomagając im lepiej zrozumieć i przeżyć Bożą miłość. Sądził, iż ten punkt wyjścia daje gwarancję, że ewentualna poprawa dokona się z przekona- 
nia $^{7}$. Prorok Jeremiasz będąc świadkiem reformy religijnej Jozjasza zauważył, iż jest niemożliwy powrót ludu do ścisłej wspólnoty z Jahwe w Przymierzu poprzez zewnętrzny nacisk. Wprost przeciwnie, nacisk zewnętrzny stał się nawet dodatkową przeszkodą w nawróceniu Judejczyków poprzez wywołanie wrogich reakcji. Jeremiasz obserwując to nabrał głębokiego przeświadczenia, że nawrócenie może się dokonać jedynie dzięki wewnętrznemu impulsowi człowieka i jego osobistej decyzji płynącej z przekonania. Człowiek musi wejść w siebie, zastanowić się nad sobą i swoim postępowaniem, aby słusznie ocenić samego siebie, swoje złe postępowanie i jego konsekwencje. Jest to warunek, bez którego nie można zrobić ani kroku w nawróceniu. Aby spowodować u ludu Królestwa Judzkiego opamiętanie się i powrót do serdecznej więzi z Jahwe wynikający z osobistej decyzji, poszedł po linii proroka Ozeasza i dlatego ukazał wywierający wielkie wrażenie obraz Boga wiecznej miłości. Bóg wyznaje: ,jestem bowiem łaskawy (kî ḥāsîd 'ănî $/ 3,12)^{8}$, a zapowiadając przyszłą świetność Izraela mówi: „Wtenczas przywrócę ci zdrowie i z ran twoich cię uleczę [...] Oto ja odwrócę niewolę namiotów Jakuba i ulituję się nad ich siedzibami" (30,17-18). Bóg, zapowiadając swą łaskawość w epoce odnowienia (perf. jako fut. prorockie), mów: „Znajdzie laskę (māsā'hënn) na pustyni naród uratowany od miecza; Izrael pójdzie do miejsca swego spoczynku. Jahwe objawi mu się z daleka. Ukochałem cię miłością odwieczną, dlatego też zachowałem dla ciebie łaskawość (měšāk tîk hāsed)" $(31,2-3)$.

Hēn wyraża ideę pełnego życzliwości pochylenia się Boga nad Izraelem, łaskawości Boga dla Izraela9 ${ }^{9}$. Łaskawość Jahwe dla swego ludu wyraził Jeremiasz także słowem hẹesed, które zawiera nie tylko postawę nacechowaną życzliwością, ale także i wierną na zasadzie wewnętrznego zobowiązania. Ponieważ Bóg zawarł Przymierze z Izraelem, słowo to zawiera w sobie nie tylko zobowiązanie o charakterze moralnym, lecz także i prawnym. Jednak ten obowiązek prawny ze strony Boga wygasł, ponieważ Izrael złamał to Przymierze ${ }^{10}$. Prorok tak akcentuje hesed, że wydaje się ono streszczać istotę Bożą (por. Ps $145,17)$, chociaż inne teksty Starego Testamentu wskazują na świętość jako Jego istotę (por. Ps 22,4; Oz 12,7; Iz 40,25; Ha 3,3; Hi 6,10). Motywem nieu-

${ }^{7}$ J. Ho me r s k i, Pojednanie z Bogiem w Starym Testamencie, [w:] Warszawskie Studia Biblijne, pod red. ks. J. Fra n k ow ski e go i B. Wid ły, Warszawa 1976, s. 45.

${ }^{8}$ Słowo hāsîd (łaskawy) występuje ze słowem Bóg jeszcze tylko w Ps 145,17; por. H. Ring ge rn, H.J. F a bry, häsî̀ ThWAT III, s. 85.

${ }^{9}$ W.F. L of th ou se, Chen and Chesed in the Old Testament, ZAW 51(1933) s. 29-35; W. L. R e ed, Some Implications of Hèn for OT Religion, JBL 73(1954) s. 36-41; D. R. A p-Thomas, Some Aspects of the Root HNN in the OT, JSS 2(1957) s. 128-148; J. Guillet, Grâce, $V_{\text {thB }}^{2}$, s. 512-518, J. Schildenberger, Gnade, BThW ${ }^{3}$ I s. 595-599; E. Wurthwein, Grande Gottes II, RGG ${ }^{3}$ II s. 1632-1634;W. Pe sc h, Gnade I, HTG I s. 548-550; H.J. S to e be, Hnn gnädig sein, THAT I s. 587-597; H. Conzelmann-W. Zimmerli, Charis, ThWNT IX s. 366-393.

10 W.F. L of th ou se, jw., s. 29-35; H.J. S t o e be, Bedeutung und Geschichte des Begriffes häsäd, Münster 1950: tenże, Bedeutung des Wortes häsäd im AT, VT (Suppl) 2 (1952) s. 244 254; tenże, haésaed, Güte, THAT I s. $600-621$; H. J. Zob el, hesed, ThWAT III s. 48-71. 
stannej łaskawości Boga jest niezmordowana miłość ('ahăbāh) ${ }^{11}$.

Jak prorok Ozeasz $(2,17)$, tak też i Jeremiasz argumentuje przede wszystkim historycznie. Jahwe ujął Izraela „za rękę, by wyprowadzić z ziemi egipskiej" $(31,32)$ i podprowadził pod Synaj, by tam wejść z nim w szczególną wspólnotę poprzez Przymierze, którego treść wyraża jego formula: „będę Waszym Bogiem, wy zaś będziecie moim narodem" $(7,23 ; 11,4 ; 24,7 ; 30,22 ; 31,1.33$; 32,38). Poprzez zawarcie Przymierza Izrael stał się: „świętością dla Jahwe, pierwocinami Jego plonu. Wszyscy, którzy go spożywają stają się winni, spada na nich nieszczęście - głosi Jahwe" $(2,3)$. Izrael jako szczególna własność Jahwe jest więc nietykalny, ponieważ, jak pod karą zakazane jest używanie pierwocin poświęconych, tak też nie ujdzie nikt karzącej Bożej interwencji, kto targnie się na Izraela. Szczególna więź Jahwe z narodem została ukazana w symbolu lnianego pasa: „Bo jak pas przylega do bioder męża, tak ja sprawiłem, że przylgnął do mnie cały Dom Izraela i cały Dom Judy — orzeka Jahwe - aby mi był ludem i sławą, chlubą i ozdobą” $(13,11)$. Określenie „Iniany” akcentuje szczególną jego wartość, bowiem materiał lniany uchodził za szczególnie cenny i nosili go przede wszystkim kapłani ${ }^{12}$. Wskutek Przymierza Izrael stał się „przodującym narodem (berō’š hagôjim)” $(31,7)$, „dziedzictwem” (ḥēleq) Jahwe, „rozkosznym dziełem Jahwe (ḥeleqātî ḥeme dātî)”, „winnicą (kerem)” (12.10). „Dziewicą i Córką mojego ludu (niše be rā(h) betûlat bat cammî)" $(14,17)$, „oliwką zieloną zdobną w pyszny owoc (zajit racănān jep̄è $(h) \bar{p}^{\mathrm{e}}$ rîtō' ar) $(11,16$; por. Oz. 14,7). Również w. 14,9 podkreśla szczególne zżycie narodu $\mathrm{z}$ Jahwe, ponieważ jako własność nosi imię swego właściciela i pana podobnie jak żona nosi imię męża (Iz 4,1; Jr 7,10). Bóg otoczył Izraelitów ojcowską opieką szczęśliwie prowadząc przez pustynię pełną niebezpieczeństw $(2,6)$ i oddając im swą najpiękniejszą posiadałość $(2,7 ; 3,19)$.

Również w przyrodzie każe Jeremiasz dostrzec troskliwą dobroć Boga. To Jahwe przecież zsyła na czas bezcenny dla życia Izraelitów deszcz, wiatry i błyskawice - zapowiedź deszczu $(5,24 ; 10,13 ; 14,22)$. W dotychczasowym, jakże życzliwym postępowaniu Jahwe w stosunku do Narodu Wybranego nie może znaleźć jakiejkolwiek nieprawości, która mogłaby być powodem odejścia Izraela od Przymierza z Nim (2,5.8).

Prorok Jeremiasz, podobnie jak i inni prorocy, zgodnie $\mathrm{z}$ mentalnością semicką, aby uderzyć umysły i serca Izraelitów miłością Jahwe, która zawarła

11 J. Ziegle r, Die Liebe Gottes bei den Propheten (Alttestamentliche Abhandlungen XI(3) Münster 1930; D. W. Thom as, The root'hb 'love' in Hebrew, ZAW 57(1939) s. 57-64; F. B u ck, Die Liebe Gottes beim Propheten Osee, Rom 1953; O. S chillin g, Die alttestamentlichen Auffassungen von Gerechtigkeit und Liebe, [w:] Festschrift für Meinertz, Münster 1951, s. 9-27; J. G uille t, Leitgedanken der Bibel, Luzern 1954, s. 29-111; C. W ié n e r, Recherches sur l'amour pour Dieu dans l'AT. Paris 1957; W. Zi m m e rli, Liebe. II; Im AT, RGG ${ }^{3}$ IV, s. 363-364; V. W a r n a ch, Liebe, BThW ${ }^{3}$ II, s. 927-965; E. J e n n i, 'hb lieben, THAT I, s. 60-73; J. B e r gma n, A. Hald ar, G. Walli s, 'ahab, ThWAT I, s. 105-128.

${ }^{12}$ E. B a u man n, Der linnene Schurz Jer 13,1-11, ZAW 65 (1953) s. 77-81; A. va n de n Born, Gürtel, BL ${ }^{2}$, s. 645 . 
się w akçie Przymierza, używa różnych obrazów. Przeświadczenie Judejczyków o miłości Jahwe ku nim zawartej w Przymierzu powinno wzbudzić w ich sercach serdeczną miłość ku niemu. Wyrażającą się w wierności temu Przymie$\mathbf{r z u}^{13}$. Jeremiasz będąc duchowym spadkobiercą Ozeasza podejmuje jego symbol miłości między kobietą i mężczyzną $(2,2.20 .32 ; 3,1)^{14}$. Terminologia małżeństwa — zdaniem A. Nehera ${ }^{15}$ — jest najbardziej udaną transpozycją Przymierza. Miłość stała się nowym określeniem Przymierza. Prorok Jeremiasz posłużył się Ozeaszowym obrażem miłości między kobietą i mężczyzną, by Naród Wybrany zachęcić do powrotu do wierności Przymierzu z Jahwe. Jeremiasz przypomina mu smak miłości z Jahwe i wyróżnia w niej podwójną miłość: miłość narzeczeńską i miłość u zarania małżeństwa (2,2 n). Miłość narzeczeńska wypełnia okres od wyprowadzenia z Egiptu do zawarcia Przymierza. To było w religijności Izraela coś nadzwyczaj pięknego. Od zawarcia Przymierza rozpoczyna się okres miłości małżeńskiej, którym również można się zachwycić, mimo iż trafiały się upadki, ponieważ Izrael umiał czynić pokutę ${ }^{16}$.

Serdeczną więź, która zaistniała między Bogiem a Izraelem przez Przymierze mocno akcentuje również relacja ojciec—syn ${ }^{17}$. Jeremiasz jednak, podobnie jak Ozeasz, wzbogaca tę ideę podkreśleniem niezmierzonej czułości Jahwe jako Ojca (Oz 11,3 n. 8 n; Jr 3,19; 31,20). Ponadto prorok z Anatot jako pierwszy nadaje Bogu tytuł Ojca. Izrael jako niewierny syn, karany przez Jahwe, uświadamia sobie niezwykłą dobroć swego Ojca i zwraca się do Niego: „Mój Ojcze! Tyś Przyjacielem mojej młodości?” $(3,4)$. Bóg zrobił wszystko, by podnieść swój lud do „rangi syna” i zechciał być nazwany słowem „Ojcze” $(3,19)$. Ponadto tytułem „syn” mianuje Izraela sam Jahwe: „Jestem Ojcem dla Izraela, a Efraim jest moim pierworodnym" $(31,9)$. Kreśląc obraz Boga - Miłości w mowach pocieszających, posługuje się Jeremiasz także znanym na całym Wschodzie i w Piśmie świętym ${ }^{18}$ obrazem pasterza. Jahwe jest Pasterzem za-

${ }^{13}$ P. v a n Im s choot, Théologie de l'Ancien Testament I, Paris 1954, s. 66 n.

14 Por. C. Wié ne r, „Fiançailles” ou ,epousailles”, RevScR 44(1956) s. 403-407; V. Della gi a com a, Israel Sposa Di Dio. La metafora nuziale del V. T., Roma-Verona 1961, s. 41-50; M. F. La can, Époux/Épouse, VThB 2 , s. 366-370.

${ }^{15}$ L'Essence du Prophétisme, Paris 1955, s. 255.

16 A. Ne her, Le symbolisme conjugal; expressions de l'histoire dans l'Ancien Testament, RevScPhilosTheol 34(1954) s. $31 \mathrm{n}$.

${ }^{17}$ L. Moraldi, La paternità di Dio nell'Antico Testamento, RBibIt 7 (1959) s. 44 -56; W. Marchel, Abba, Père! La prière du Christ et des chrétiens, Romae 1963, s. 45-52; D. J. Mc $\mathrm{Carth} \mathrm{y}$, Notes on the love of God in Deuteronomy and the Father-Son Relationship between Jahweh and Israel, CBQ 27 (1965), s. 144-147.

18 V. H a m p, Das Hirtenmotiv im Alten Testament, [w:] Festschrift Kard. Faulhaber, München 1949, s. 7-20; P. S a m a in, Le pasteur dans la Bible, „Revue Dioec. de Tournai” 5(1950) s. 15-25; J.G.S.S. Th o $\mathrm{m}$ p s on, The Shepherd-Ruler Concept in the Old Testament and its Application to the New Testament, ScotJTh 8(1955) s. 406-418; V. M a a g, Der Hirte Israels. Eine Skizze von Wesen und Bedeutung der Väterreligion, „Schweizerische Theolog. Umschau” 28(1958) s. 228; G.J. B o t $\mathrm{e}$ r w e ck, Hirt und Herde im Alten Testament und im Alten Orient, [w:] Festgabe f. Kard. J. Frings, Köln 1960, s. 339-352; H. Th o m a n n, Jahwe Hirte der Seinen, Rom 1963: J. B. B a u e r, Hirt, BThW ${ }^{3}$ II, s. 733-735; J. Je re mi as, Poimēn/ktl, ThWNT VI, s. 485-489; C. Lesquivit, X. Léon-Dufour, Pasteur-Troupeau, VThB ${ }^{2}$, s. 917-921. 
troskanym o swoje owce $(23,3 ; 31,8.10 ; 50,19)$ i stara się o najlepszy pokarm dla nich $(23,1 \mathrm{n})$. Miłość Bożą przedstawia Jeremiasz także w metaforze gospodarza winnicy $(2,21 ; 5,10 ; 6,9 ; 12,10)$, rozwiniętej wcześniej przez proroka Izajasza $(\mathrm{Oz} 10,1 ; \mathrm{Iz} 5,1-5 ; 27,2-5)$. Po tej linii pójdzie również Chrystus, przedstawiając grzesznikom niepojętą miłość Boga, który z radością tuli nawracającego się grzesznika do swego ojcowskiego serca, wszystko przebaczając i wspaniałomyślnie obdarowując.

\section{Dogtębne przeżycie mitosierdzia Boga}

Czy Izrael — zhańbiona oblubienica może w ogóle powrócić do Boga? Oto poważne pytanie, które postawił narodowi Jeremiasz już w pierwszych wystąpieniach $(3,1-3)$. Wychodząc z powszechnie znanego prawa w Izraelu, wykluczającego powtórne małżeństwo pierwszego małżonka $\mathrm{z}$ legalnie oddaloną żoną, którą w międzyczasie pojął ktoś inny (Pwt 24,1-4), chce powiedzieć rodakom, iż niestety, nie mają prawa powrotu do Boga tym bardziej, że jako oblubienica Jahwe przez różnorodne formy bałwochwalstwa niejako cudzołożyli z wieloma kochankami.

Prorok Jeremiasz opiera więc swoje usilne wezwanie do nawrócenia na wierze w nieznające granic miłosierdzie Boże gotowe przebaczyć wszystko, co było złe w życiu Izraelitów ${ }^{19}$. Bóg mówi: „Przebiegnijcie ulice Jerozolimy, zobaczcie i przekonajcie się, przeszukajcie jej place, czy znajdziecie człowieka, (czy jest ktoś), kto postępuje sprawiedliwie, kto szuka prawdy, a Ja jej przebaczę” $(5,1)$. Zapowiadając Nowe Przymierze, Bóg oznajmia: „Przebaczę, bowiem ich winy i grzechów ich już pamiętać nie będę" $(31,34)$. Przebaczenie przewin wygnańców zapowiada Bóg także podczas oblężenia Jerozolimy $(33,8)$. Wiara w miłosierdzie Boże pochylające się nad nędzą Izraela - Odstępcy, a przechodzące wszelkie domysły ludzkie, ma Izraelitów przekonać o tym, że Bóg nie jest mściwy i dlatego możliwy jest powrót do Boga: „Wracaj izraelska zdrajczyni! - mówi Jahwe. Nie okażę wam gniewnego oblicza. Jestem bowiem łaskawy - głosi Jahwe - nie będę się wiecznie gniewał" (3,12; por. $3,22 ; 4,1 \mathrm{n} ; 7,3 ; 18,8 ; 26,3,19 ; 29,11 ; 31,34-37 ; 36,3)$. Gniew Jahwe nie jest ślepy i kapryśny, jak to widzimy u bogów Babilonii czy Grecji. Gniew Jahwe powodowany odstępstwem Izraelitów ma granice $(10,24 ; 30,11 ; 46,28)$ i jest gotów zawsze ustąpić miejsca miłosierdziu. Zarówno Ozeasz jak i Jeremiasz nie zaprzestali zapowiadać nadejścia najsurowszych kar, jednak równocześnie zwracają uwagę na tkliwość Bożego serca. Ozeasz stwierdził, że kiedy Bóg

${ }^{19}$ L. St op nicki, Miłosierdzie Boże w świetle Pisma św. i nasza na nie odpowiedź, [w:] „Bo Jego mitosierdzie na wieki", pod red. ks. L. B al t e r a, Poznań 1972, s. 21-32; J. Ch miel, Starotestamentalna semantyka biblijna miłosierdzia, [w:] Encyklika Ojca Świętego Jana Pawła II o Bożym mitosierdziu Dives in misericordia. Tekst i komentarz, Kraków 1981, s. 75-82; S. G r z y b e k, Miłosierdzie Boże w ST, tamże s. 83-89. 
postanowił: „Domowi Izraela nie będę już okazywał miłosierdzia i już mu nie przebaczę" $(1,6)$ i zdecydował się zesłać nań karę, wtedy wzdrygało się na to Jego serce i rozgrzewały Jego wnętrzności $(11,8)$ i nie chcial już, aby wybuchnął płomień Jego gniewu $(11,9)$. Podobnie czyni Jeremiasz: „Czy Efraim nie jest mi synem drogim, dziecięciem najmilszym? Bo ilekroć mu grożę, zawsze o nim troskliwie pamiętam. Przeto wzrusza się nad nim moje serce; okażę mu miłosierdzie - głosi Jahwe $(31,20)$ ". Jahwe nie będzie pałał gniewem na wieki $(3,12)$; wprost przeciwnie, poruszony wewnętrznie miłosierdziem, pragnie jak najszybszego nawrócenia się grzeszników, aby im błogosławić (4,1 n).

\section{Odczucie wielkości Boga}

W ponownym odkryciu Boga oprócz świeżego zachwytu dla miłości Jahwe jest miejsce na bojaźń $(2,19 ; 32,39 ; 33,9)$, czyli poczucie szacunku dla Niego ${ }^{20}$, która winna się zrodzić wskutek doświadczenia wszechmocy Jahwe: „Czyż mnie się bać nie będziecie - mówi Jahwe - czyż nie zadrżycie przede mną? Morzu piaskiem wyznaczyłem granice, odwieczny próg, którego nic nie przekroczy. Burzą się (odmęty), ale nie przemogą, piętrzą się jego fale, lecz nie mogą popłynąć dalej" $(5,22$; por. 10,7$)$. Innym motywem szacunku dla Jahwe według Jr 5,24 jest wdzięczność za jego opatrzność nad krajem Judejczyków: „I nie postanowili w swym sercu: odczujmy lęk wobec Jahwe - Boga naszego, który zsyła deszcze nasycające zagony; (opady jesienne i wiosenne) w swej porze, które chronią nam plony" (por. 33,9).

\section{Zawstydzenie, żal i wyznanie grzechów}

Uświadomienie sobie dobroci miłosiernego Boga, a zarazem straszliwej złości grzechu, powinno wywołać u Izraelitów wstyd, iż się dopuścili grzechu, odrazę do niego oraz żal, że aż tak obrazili Boga i skrzywdzili bliźnich ${ }^{21}$. Dlatego Jeremiasz spodziewał się, że Izraelici wezmą sobie to wszystko „do serca” (Jr 12,11), uznają haniebność i obrzydliwość swojego postępowania $(6,15)$ i w konsekwencji zawstydzą się, zarumienią się $(6,15 ; 8,12 ; 31,19)$. Słowo „zawstydzić się" w sensie religijnym prorok z Anatot użył aż 36 razy ${ }^{22}$, co wskazuje na to, jak bardzo zależało mu na tym ważnym momencie w drodze Izraela ku Bogu. W grzechu jest bowiem swoisty bezwstyd i buta, co sprawia, że Izrael

${ }^{20}$ P. van Im schoot, jw. (przyp. 13) II s. 98-101; B. Olie r, La crainte de Dieu, comme valeur religieuse dans l'Ancien Testament, Bruxelles 1960; S. Pl a th, Furcht Gottes, Der Begriff yr' im Alten Testament, Stuttgart 1963; J. B e ck e r, Gottesfurcht im Alten Testament, Rom 1965; P. A uvary - P. Gre lot, Crainte de Dieu, VThB ${ }^{2}$, s. 219-222.

21 J. Hom ers ki, jw. (przyp. 7), s. 44.

22 J. Homers ki, tamże, s. 43; H. Seebass, bos, ThWAT I, s. $573-575$ i 579 n. 
nie widzi swego złego postępowania, ma upodobanie w grzechu i jest zuchwały. Aby mógł rozpocząć się proces nawrócenia, powinno się dokonać przewartościowanie fałszywych wartości; w miejsce zarozumiałego bezwstydu i buty musi pojawić się prawdziwe zawstydzenie. Izrael musi poznać i uznać, że nie ma się z czego chlubić ani chełpić: wprost przeciwnie, powinien się głęboko zawstydzić (por. 6,$15 ; 8,12$ ). W przeżyciu wstydu zawiera się potępienie i obrzydzenie grzechów: „Doprawdy oszustwem są wzgórza i wrzawa na górach! Doprawdy, tylko w Jahwe, naszym Bogu jest zbawienie Izraela! Ohydny bożek pożerał (od naszej młodości) owoc pracy naszych ojców: ich owce i woły, ich synów i córki. Leżymy w naszym wstydzie i nasza hańba nas okrywa! Bo zgrzeszyliśmy przeciw Jahwe, Bogu naszemu, my i nasi ojcowie, od naszej młodości aż po dzień dzisiejszy, i nie słuchaliśmy głosu Jahwe, Boga naszego" $(3,23-$ 25). Uczucie wstydu Izraelitów do bóstw obcych pogłębia fakt, iż Baal-bōšet $=$ hańba, pożerał ('ak $\underline{k}^{\mathrm{e}} \mathrm{la}(\mathrm{h})$ plony pracy, dobytek, a nawet dzieci. Jest tutaj prawdopodobnie aluzja do oficjalnego kultu bóstw obcych za Manassesa i Amona, który starsi pamiętali z okresu swej młodości. Jakkolwiek słowo bōšet, które wyraża obrzydzenie do Baala jest prawdopodobnie wtórne w stosunku do $\mathrm{ba}^{\mathrm{c}}$ al - wynik późniejszego zastąpienia pierwotnego bacal - to jednak słowo to jest bardzo odpowiednie w tym kontekście. Przeto termin ten jest elementem gry słownej obok wyrażeń określających wstyd w w. 25. Efektem porzucenia Boga jest nie tylko obrzydzenie sobie grzechów, lecz także przeżycie hańby. Prorok wyraża to dwoma synonimicznymi słowami: bōšet i kelimmā(h). $\mathrm{Z}$ tym, że to drugie ma znaczenie bardziej pejoratywne i znaczy lżenie, wstyd, hańba. Na przeżycie wstydu składa się także smutek, boleść, żal z powodu win popełnionych: „Słuchaj! Rozbrzmiewa na wzgórzach błagalny płacz synów Izraela. Bo zdeprawowali swe drogi i zapomnieli o Jahwe, swym Bogu" $(3,21)$. Jeremiasz w proroczym widzeniu dostrzega na wyżynach ( (ّ ${ }^{\mathrm{e}}$ pajîm) - miejscach bałwochwalstwa $(3,2)$ zamiast cudzołóstwa Izraela, czyli hałaśliwych, pełnych zgiełków obrzędów, płacz Izraelitów wołających o zmiłowanie, jakby

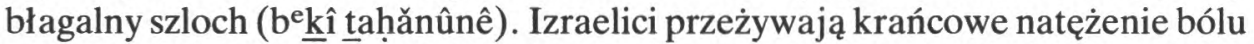
i lamentują, ponieważ wreszcie zauważyli, że są na fałszywych drogach życiowych (darekām) ${ }^{23}$ i zapomnieli o prawdziwym Bogu; wreszcie odczuwają potrzebę przebaczenia popełnionych grzechów. Izrael tak powie: „Bo gdy się odwróciłem od Ciebie - żałowałem, a skoro zrozumiałem - uderzyłem się w biodro. Wstydzę się i rumienię, gdyż noszę hańbę mej młodości” $(31,19)$. Po odejściu od Boga, Izrael się opamiętał, zrozumiał swój błąd i w końcu żałuje tego wszystkiego. Ból i skrucha wyraża się nie tylko w wewnętrznym żalu (nihamam $\left.{ }^{\mathrm{e}} \mathrm{i}\right)^{24}$, lecz także w geście bicia się w biodro, który wyraża najbłębszą skru-

${ }^{23}$ F. Notscher, Gotteswege und Menschenwege in der Bibel und im Qumran (BBB 15). Bonn 1958, s. 55 n.

${ }^{24}$ J. Ch miel, Biblijne podstawy pokuty, RBL 35(1982), s. 402. 
chę. Gest ten jest znany nie tylko w Biblii (por. np. Ez 21,17), lecz także w literaturze klasycznej ${ }^{25}$.

Swój grzech, obrzydzenie dla niego oraz ból, Izrael powinien wyznać Bogu. Wyznanie tego rodzaju jest bowiem naturalnym warunkiem przebaczenia Bożego. Wyznanie Bogu grzeszności swego postępowania spotykamy już we wcześniejszych okresach życia Izraela (np. Sdz 10,10; $1 \mathrm{Sm} \mathrm{7,6).} \mathrm{Wyznania}$ grzechów ukazane przez proroka Jeremiasza $(3,21 ; 14,7 ; 31,18 \mathrm{n})$ rozwijają i pogłębiają tę ideę. Wyznania tego rodzaju staną się szczególnie częste, głębokie i dojrzałe w późnym judaizmie ${ }^{26}$. Na pokutę nigdy nie jest za późno; każdy czas jest stosowny na nią, nawet gdy nadchodzi straszna kara $(6,26)$.

Tak więc najważniejszym warunkiem nawrócenia — według Jeremiasza jest ponowne otwarcie się na słowo Jahwe kierowane do Izraelitów przez proroków. Od spełnienia tego warunku zależy możliwość zrealizowania innych warunków nawrócenia. Pod wpływem słów prorockich Izraelici zrozumieją zło swego postępowania. Słowo Boże bowiem pomagając Ludowi Wybranemu pełniej przeżyć odwieczną miłość Boga, Jego miłosierdzie skłonne do przebaczenia wszystkich grzechów oraz potęgę Boga, wzbudzi w nim przekonanie o możliwości powrotu do Boga. To pełniejsze doświadczenie Boga, a zarazem uświadomienie sobie obrzydliwości swego postępowania spowoduje u Izraelitów również zawstydzenie, żal i wyznanie grzechów.

\section{ISTOTNE CECHY NAWRÓCENIA}

Prorok Jeremiasz nawołując ustawicznie do nawrócenia, musiał także jasno określić, na czym ono polega. Podania istotnych cech nawrócenia domagała się także konieczność sprostowania fałszywych pojęć Izraelitów w tym względzie. Izraelici byli bowiem skłonni przeżywać nawrócenie w sposób powierzchowny i obrzędowy ${ }^{27}$. Wierność Bogu i Przymierzu utożsamiano zaś z kultem sprawowanym dla Jahwe, a zwłaszcza z ofiarami $(\mathrm{Jr} 6,20)$. Już w chwili wzywania Izraelitów do nawrócenia, zbytnio akcentowano w nawróceniu następujące akty pokutne: posty $(\mathrm{Sdz} 20,26 ; 1 \mathrm{Krl} 21,9-12 ; \mathrm{Jr} 14,12 ; 36,6.9)$, rozdzieranie ubrań i ubieranie worów pokutnych (1 Krl 20,31 n; 2 Krl 6,30; 19,1 n; Iz 22,12; $\mathrm{Jr} 4,8 ; 6,26)$, leżenie w popiele ( $\mathrm{Sm} 12,16)$, wyznania grzechów (Sdz 10,10; 1 $\mathrm{Sm} 7,6)$, modlitwę pokutną ${ }^{28}$, okrzyki bólu, lamenty, zawodzenie i płacze (Sdz 2,$4 ; \mathrm{Jr} 4,8$ ), prośbę o wstawiennictwo wodza lub proroka (Wj 32,30 n; $1 \mathrm{Krl}$ $8,22-53)$. Ponieważ zewnętrzna strona nawrócenia była często przeakcento-

${ }^{25}$ Hom e r, Iliada 16.125; tenże, Odyssea 13,198.

${ }^{26} \mathrm{R}$. Schnacke n, Bekenntnis, $\mathrm{BL}^{2}, \mathrm{~s} .188 \mathrm{n}$.

27 J. Gible t, P. G relot, Penitence-Conversion, VThB ${ }^{2}$, s. 951; E. Li i ińs ki, La liturgie penitentielle dans la Bible, Paris 1969.

${ }^{28}$ Psalmy pokutne i niektóre fragmenty pozostałych psalmów (np. 25,7; 41,5; 65,4). 
wana, a brak było zmiany wewnętrznej postawy, nawrócenie stawało się rodzajem magii, z czym prorocy nigdy nie mogli się zgodzić. Stąd rodziły się nawoływania poprzedników Jeremiasza do podjęcia właściwego nawrócenia (1 Sm 15,22 n; Am 4,6.8-11; Oz 6,6; Iz 1,10-17; 29,13).

Teologia nawrócenia rozwijała się w Starym Testamencie paralelnie do teologii grzechu ${ }^{29}$. Te dwa tematy biblijne są najściślej korelatywne. Sprawa ta ukazuje się wg J. Gibleta ${ }^{30}$ tak, jakby poznanie grzechu wzrastało w proporcji do wysiłków wkładanych przez ludzi w sprawę uwolnienia się z jego niewoli. Prorok Jeremiasz, w porównaniu ze swymi poprzednikami, znacznie pogłębił teologię grzechu ${ }^{31} \mathrm{i}$ w konsekwencji także i teologię nawrócenia. Prorok ujmuje bogatą rzeczywistość nawrócenia zarówno w aspekcie negatywnym jak i pozytywnym.

Wzywając do nawrócenia w ujęciu negatywnym domaga się porzucenia wszystkiego co jest przeciwne Bogu, a zwłaszcza Jego świętości, i dlatego podobnie jak poprzednicy - wzywa do porzucenia grzechów. Ten aspekt nawrócenia skonkretyzował Jeremiasz w mowie z początku panowania Jojakima, a więc prawdopodobnie z 609 roku, zawartej w rozdziale VII jego Księgi: ,„[...] nie będziecie krzywdzić cudzoziemca, sieroty ani wdowy, ani przelewać niewinnej krwi na tym miejscu, ani też nie pójdziecie za obcymi bożkami na własną zgubę" $(7,6)$. Jeremiasz nakazuje więc zaprzestać krzywdzić ubogich i sieroty, co napiętnował już wcześniej $(2,34 ; 5,28)$, a także cudzoziemców, ponieważ Tora uważała, że ci ludzie są w najgorszej sytuacji życiowej, gdyż są bezbronni (Wj 22,20 n; Pwt 24,17; 27,19). W aktualnym programie postępowania Izraelitów musi także mieć miejsce zaprzestanie rzadkiego, ale szczególnie ciężkiego grzechu morderstwa w świątyni ( 2 Krn 24,15-22; Mt 23,35; Łk 11,51). Ponadto szczególną uwagę mają zwrócić Izraelici na to, by nie kraść i nie zabijać, nie cudzołożyć i nie przysięgać fałszywie, nie palić kadzidła Baalowi i nie chodzić za obcymi bożkami $(7,9)$. Jeremiasz tutaj - podobnie jak Ozeasz w 4,2 - nawiązuje wyraźnie do Dekalogu (Wj 20,1-17). Jeremiasz kładzie jednak nacisk nie tyle na odwrócenie się od złego postępowania, co na zasadnicze wyeliminowanie zatwardziałości serc - głównej przeszkody w drodze do Boga $(3,17 ; 7,24 ; 9,13 ; 11,8 ; 13,10 ; 16,12 ; 23,17)^{32}$.

W aspekcie pozytywnym nawrócenie to „ponowne przywrócenie pierwotnego statusu” w sensie ,powrotu do pierwotnej więzi z Jahwe”33, która miała

${ }^{29}$ J. Giblet, P. Grelot, jw. (przyp. 27), s. 953; A. Gelin, Le péché dansl'A.T., [w:] Théologie du péché, Tournei-Paris 1960, s. 23-47; J. G ible t, Le sens de la conversion dans l'A.T., Maison-Dieu 90(1967) s. 79-92.

30 J. Giblet, jw., s. 79.

${ }^{31}$ A. Fournel, P. Re my, Le sens du péché dans Jeremie, BiViChr 5(1954) s. 34 46; E. B e a u c a m p, Péché dans l'Ancien Testament, DBS VII, s. 408-471; J. Sch re in e r, Przez grzech odwraca się cztowiek od Boga, ConcPol 6-10(1969) s. 260-276.

${ }^{32}$ H. Gross, jw. (przyp. 4), s. 160.

${ }^{33}$ W. H. Wolf f, Das Thema ,Umkehr” in alttestamentlichen Prophetie, ZThK, $134 \mathrm{n}$. 
miejsce szczególnie w okresie między wyjściem z Egiptu, a zawarciem Przymierza u podnóża góry Synaj. Okres ten określa Jeremiasz jako czas „młodości” i „narzeczeństwa” $(2,2)$ i ukazuje go jako okres głębokiego przywiązania, szczególnej wierności i gorącej miłości Izraela do Boga. W sposób mniej wyraźny $(2,3)$ jako również idealny okres w historii Izraela ukazuje Jeremiasz czas „zaślubin”, czyli zawarcia Przymierza. Nawrócenia nie powinno się oczywiście rozumieć w sensie absolutnego powrotu do pierwotnego statusu, ponieważ rzeczywistość, do której się zawraca, staje się odmienną w porównaniu z tą, którą się opuściło ${ }^{34}$. I tak chociaż Jozjasz chciał powrócić do pierwotnego statusu, to jednak to stare okazało się czymś zupełnie nowym $(2 \mathrm{Krl} 22-23$; por. $2 \mathrm{Krn}$ 34-35).

Źródłem głębokiej wspólnoty między Bogiem a ludem było Przymierze. Spośród wszystkich narodów jedynie Izrael stał się „drogocenną własnością

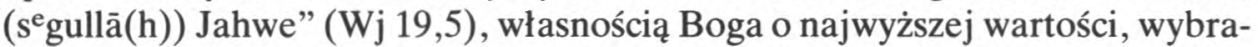
ną i wyłączną. Tę przynależność do Jahwe wyraża i z niej się wywodzi formuła Przymierza: „wy będziecie moim ludem, a ja waszym Bogiem”35. W przeciwieństwie do przymierzy i związków naturalnych, jakie łączyły inne ludy z ich bogami, Przymierze Jahwe z Izraelem uwarunkowane jest wiernością przepisom Przymierza. Wspólnota Izraela z Jahwe przez Przymierze nie pogłębia się więc w sposób automatyczny, lecz w miarę wzrostu wierności temu Przymierzu. Stąd nawrócenie to aktualizacja Przymierza, to powrót do wierności Przymierzu. Współcześni teologowie są szczególnie uwrażliwieni na ustawienie biblijnej koncepcji nawrócenia w perspektywie Przymierza ${ }^{36}$. U proroków VIII wieku berît (przymierze), odgrywało podrzędną rolę, chociaż sama idea była im znana ${ }^{37}$. I tak prorok Amos w swej Księdze użył słowo berît tylko raz $(1,9)$, jednak rozwija ideę wyboru Izraela. U proroka Ozeasza termin berît występuje już 5 razy. W wierszach 6,7 i 8,1 zarzuca Izraelitom złamanie Przymierza, ale dominuje u niego motyw związku małżeńskiego. U Izajasza to słowo występuje zaledwie 4 razy, a w tym tylko raz dla określenia Przymierza z Jahwe w wyrażeniu: „złamali wieczyste Przymierze” (24,5). Prorok Jeremiasz w swych mowach z pierwszego okresu działalności ani razu nie użył słowa berît; dla oddania więzi, jaka zaistniała między Jahwe a jego ludem, posługiwał się symbolem małżeństwa. Po odnowieniu Przymierza przez Jozjasza prorok podjął pojęcie berît $\mathrm{i}$ wkomponował w swoje posłannictwo. Jako pierwszy z proro-

${ }^{34}$ G. Fohre r, Umkehr und Erlosung beim Propheten Hosea, ThZ 11(1955) s. 164, odn. 7.

${ }^{35}$ F. Zor ell, Lexicon Hebraicum et Aramaicum, Roma 1960, s. 545; H. Wil d berge r, Jahwes Eigentumsvolk, Zurich 1960, s. 73-77; H. G r o s s, Volk Gottes im Altem Testament, [w:] Die Kirche-Volk Gottes, wyd. H. Asmuss e n, Stuttgart 1961, s. 74; J. Kudasie wicz, Lud Boży, AK 68(1965) s. 280 n.

36 M. in.: P. van Imsch oot, L'Alliance dans l'A.T., NRTh (1952) s. 785-805; W. Ei ch rodt, Theologie des A.T. I, Berlin 1957, s. 9-32; P. Gre lot, Sens chretien de l'AT., Tournai 1962.

${ }^{37} \mathrm{M}$. Weinfeld, $b^{e}$ ritt, ThWAT I, s. 807. 
ków wyraźnie przypomina Izraelitom zawarcie Przymierza z Jahwe przez ich ojców: „Tak mówi Jahwe, Bóg Izraela: Ja zawarłem Przymierze ('ānōkî kāratî $\mathrm{b}^{\mathrm{e}}$ rît) $\mathrm{z}$ ojcami waszymi w dniu, w którym wyprowadziłem ich z ziemi egipskiej z domu niewoli" $(34,13$; por. 7,22 n i 11,8). Odejście od Boga natomiast określa „złamaniem Przymierza” (11,10). Przymierze zostało złamane wskutek brutalnego przekraczania Prawa, a szczególnie wskutek bałwochwalstwa: „Ponieważ opuścili Przymierze z Jahwe, swoim Bogiem, a bili pokłony innym bogom i służyli im" $(22,9)$. Dlatego jest rzeczą zrozumiałą, iż Jeremiasz wielokrotnie wyrzuca im to lekceważenie sobie Prawa Przymierza $(6,19 ; 8,7 ; 9,12$; $16,11 ; 32,23 ; 44,10.23)$. Nie małą winę za to ponoszą oficjalni komentatorowie Prawa $(8,8)$. Prorok Jeremiasz w swym wezwaniu do nawrócenia przypomniał najmocniej z proroków obowiązek zachowania Prawa.

Zapowiedziane nawrócenie ludu Jahwe będzie polegać więc na pełnej realizacji Przymierza poprzez wierność Jego Prawu (30,21-22; 31,1;32,37-38), a będzie to dziełem Mesjasza $(23,5=33,15)$. Na to, że nawrócenie - według proroka Jeremiasza - polega na aktualizacji Przymierza, wskazuje przede wszystkim zapowiedź odnowienia narodu przez Nowe Przymierze: „Oto nadejdą dni - głosi Jahwe - a zawrę z Domem Izraela i z Domem Judy Nowe Przymierze! Nie jak Przymierze, które zawarłem z ich przodkami, gdy ich ująłem za rękę, by wyprowadzić ich z ziemi egipskiej. To moje Przymierze oni zerwali, chociaż byłem ich władcą - głosi Jahwe. Natomiast takie będzie Przymierze, które zawrę z Domem Izraela po dniach owych — głosi Jahwe: umieszczę Prawo moje w ich wnętrzu i wypiszę je na ich sercu! i będę im Bogiem, a oni będą mi ludem!” $(31,31-33)$. Mimo zaakcentowania w powyższym tekście różnicy obydwu Przymierzy - stwierdza A. Jankowski - Nowe Przymierze - z punktu widzenia planu Bożego - będzie dalszym ciągiem synajskiego ${ }^{38}$. Również Prawo tego Przymierza nie będzie zawierało nowej treści, innych nakazów czy wskazówek; różnica w stosunku do Prawa otrzymanego u podnóża góry Synaj będzie tkwić w tym, że w Przymierzu synajskim Prawo zostało narzucone od zewnątrz i za pomocą sankcji zmuszało do posłuszeństwa. W Nowym Przymierzu Prawo stanie się wewnętrzną własnością człowieka wskutek ,wypisania go na sercu”, ,umieszczenia we wnętrzu” Izraelitów przez Boga $(31,33)$. Człowiek będzie odczuwał w sobie wewnętrzną skłonność i siłę do wypełniania woli Jahwe: „Prawo stanie się - używając określenia A. Gelina ${ }^{39}$ - czymś w rodzaju instynktu wewnętrznego, czymś w rodzaju światła wewnętrznego".

Podstawowym zaś zobowiązaniem Prawa jest wiara w Jahwe. Jeremiasz,

${ }^{38}$ Ku zbawieniu poprzez „ekonomię” starego Prawa, [w:] Drogi zbawienia. Od Biblii do Soboru, Poznań 1970, s. 116; por. Cz. J a k ubi e c, Stare i Nowe Przymierze, Warszawa 1961, s. 117120; L. St a ch owiak, Nowe Przymierze u Jeremiasza, [w:] Księga Jeremiasza (PSSTx1) Poznań 1967 , s. 529.

39 Pismo święte o człowieku (tytuł oryg. L'homme selon la Bible, tlum. Danuta Szumska, Paris 1971, s. 131. 
podobnie jak i inni prorocy oraz cały Stary Testament, rozumie ją jako ufność w Bogu, zawierzenie Jemu, Jego obietnicom, wierności, wszechmocy, prawdomówności $(3,23 ; 4,1 \mathrm{n} ; 5,12 ; 9,23 ; 14,22 ; 17,7)$. Człowiek jest bowiem tak zależny od wszechmocnego Boga, jak glina od garncarza $(18,6)$. Wzorem dla narodu jest osobista postawa Jeremiasza pełna zawierzenia Bogu $(20,11 \mathrm{n})$. Podstawą zawierzenia Jahwe jest fakt, że tylko On jest Bogiem żywym $(10,10$; por. $23,36)$. Jedynie On, w przeciwieństwie do martwych bożków, zrobionych ręką ludzką z kamienia lub drzewa, może przysięgać: „Jak (prawdą jest, że) ja żyję” $(22,24)$. Bożki natomiast są nebēlā(h) - trupem $(16,18)$, czymś martwym jak posągi; šeqer - kłamstwem, oszustwem, fałszem, ułudą $(10,14 ; 16,19)$, nie ma w nich życiodajnego tchnienia $(10,14 ; 51,17)$. Są po prostu hebel (nicością; 2,5 ; $10,3.15 ; 16,19 ; 51,18)$; są nie-bogami $(2,11 ; 16,20)$. Ponadto Jeremiasz utożsamia bożków z drzewem, kamieniem, rycinami, dziełami rąk ludzkich $(1,16$; 10,3.9) i dlatego zarzuca ludowi, że: „mówią do drzewa: 'Ty jesteś moim ojcem', a do kamienia: 'Ty mnie urodziłeś'” $(2,27)$. Swoim rodakom uświadamia także prawdę, że ich bożkowie są dziełami rzemieślnika (10,3-9) i pyta: „,czy może człowiek uczynić sobie bogów?" $(16,20)$. Może. Ale tacy bogowie nie mogą pomóc, wybawić, gdy spadnie na Izraelitów nieszczęście $(2,28 ; 14,22)$. Na swoich bożkach zawiodą się poganie $(48,13)$, co zresztą sami przyznają. Jakżeż żałośnie wyglądają bogowie, którzy nie mogą pomóc $(2,11)$, podobni do popękanych cystern bez ożywczej wody, przy wszechmocnym Jahwe, któremu można powiedzieć: „Ach, Panie, Jahwe! Oto Ty stworzyłeś niebo i ziemię wielką swoją mocą i wyciągniętym ramieniem! Żadna rzecz nie jest niemożliwa dla Ciebie” $(32,17)$. Sam zaś Jahwe wyznaje: „Ja uczyniłem ziemię, człowieka i zwierzęta, które są na powierzchni ziemi, swą wielką siłą i wyciągniętym ramieniem; i daję je, komu uważam za słuszne" $(27,5$; por. 10,$16 ; 32,27)$. Rzeczywiście Jahwe może uczynić, co chce, a świadczy o tym nie tylko stworzenie świata, lecz także wszechwładne panowanie nad nim: „Na dźwięk Jego głosu szumią wody w niebie. On sprawia, że się chmury podnoszą z krańców ziemi: On wywołuje błyskawice - zapowiedź deszczu - i wysyła wiatr ze swoich zbiorników" (10,13; por. 5,22; 31,35 n).

Jeremiasz chce więc przekonać swoich rodaków, że jedynie Jahwe można zawierzyć, jedynie w Nim można złożyć zaufanie. Jednak na to, że Jahwe będzie Bogiem Izraela, na Jego błogosławieństwo można liczyć tylko wtedy, gdy Izrael jest Jego ludem, gdy postępuje według nakazów Jahwe. Dlatego często powtarza wezwanie: „poprawcie swe drogi” $(7,3.5 ; 18,11 ; 26,13 ; 35,15)$ i ,nawróćcie się ze swych dróg" $(15,7 ; 18,11 ; 23,22 ; 25,5 ; 26,3 ; 35,15 ; 36,7)$.

Nawrócenie musi objąć najgłębsze pokłady ludzkiej osobowości i dlatego dla Jeremiasza jest sprawą serc ${ }^{40}$. Idea ta była rozwijana wcześniej przez Amo-

40 J. Gible t, jw. (przyp. 29), s. 86 nn; M. F. La ca n, Conversion et grâce dans l'Ancien Testament, LV 9(1960) s. $12 \mathrm{nn}$. 
sa $(8,11-12)$, Ozeasza $(6,6)$, Izajasza $(1,11-17)$, Micheasza $(6,6-8)$ i jest charakterystyczną dla całej tradycji prorockiej. Później Joel mówi o „rozdzieraniu serca" $(2,12 \mathrm{n})$. Natomiast Ezechiel mówi o nowym sercu, jakie winni w sobie stworzyć Izraelici, w kontekście nawrócenia ${ }^{41}$. „W języku antropologii biblijnej Starego Testamentu serce jest siedliskiem świadomej, wolnej i rozumnej osobowości człowieka, miejscem podejmowania decyzji, organem uczuć i pragnień" 42 . Dla Jeremiasza serce również jest nie tylko organem warunkującym życie $(8,18)$, lecz także środowiskiem życia wewnętrznego. W nim koncentrują się dobre lub złe myśli $(4,14)$, ponieważ ono przede wszystkim jest organem myślenia $(5,21 ; 7,31 ; 14,14 ; 23,16.20 .26)$, w nim rodzą się uczucia, np. bojaźni, lęku, radości, smutku $(4,19 ; 5,22 \mathrm{n} ; 15,16 ; 23,19 ; 32,40)$ i pragnienia $(22,17)$. Serce może unosić się też zuchwałością $(49,16)$. W sercu zapadają również decyzje $(5,23 ; 13,10)$. Serce jest także ogniskiem życia religijnego $(5,22$; $12,3 ; 17,5 ; 24,7)$. Jeremiasz chętnie używa zwrotu: „Jahwe zastępów jest sprawiedliwym sędzią, bada serca i nerki" $(11,20$; por. 17,$10 ; 20,12)$ będąc przekonany, że wartość człowieka zależy od charakteru serca, które jest źródłem dobra i zła w życiu. Dlatego nie dziwi fakt, że dla Jeremiasza prawdziwe nawrócenie to nawrócenie „całym sercem”. Już w pierwszym etapie swej działalności, w przemówieniach do zebranego przy świątyni ludu głosił: „nie nawróciła się do mnie niegodziwa siostra Juda całym sercem, lecz tylko z pozoru" $(3,10)$ i nawoływał: „Obrzezajcie się dla Jahwe i usuńcie napletki z serc waszych” $(4,4)$, „oczyść swe serce z nieprawości, Jerozolimo” $(4,14)$. W wezwaniach tych Jeremiasz domaga się wewnętrznej przemiany. Powrót do Boga musi bowiem być radykalny, prawdziwy i szczery.

Jeremiasz określając nawrócenie Judy jako nawrócenie tylko z pozoru, prawdopodobnie robił aluzję do reform religijnych podejmowanych kilkakrotnie, zwłaszcza przez Ezechiasza ( $2 \mathrm{Krl} 18,3$ n; $2 \mathrm{Krn} 29,2$-31) i Jozjasza (2 Krl 22,2 - 25; 2 Krn 34,3-35), które okazały się zbyt powierzchowne; wielu Izraelitów zewnętrznie powróciło do swego Boga, nie zmieniając swoich wnętrz $(12,2)$, by zacząć nowe życie. Izraelici zadowolili się bowiem zewnętrznymi przejawami pobożności jak pełne przepychu składanie ofiar, uroczyste obchodzenie świąt i posty, a fałszywi prorocy i kapłani wskazywali na świątynię i jej nietykalność jako absolutną gwarancję, iż żadne nieszczęście nie może ich spotkać, ignorując konieczność poprawy życia (7,2-10), a zwłaszcza położenia kresu krzywdom społecznym i bałwochwalstwu $(5,28 ; 7,5$ n.9). Tymczasem prawdziwe nawrócenie to nie tylko zewnętrzna część Boga czyli kult, w którym szczególną rolę odgrywało składanie ofiar. Niektórzy dawniejsi egzegeci pro-

${ }^{41}$ A. M. Dubarle, Le don d'un coeur nouveau, BiViChr 14(1956) s. 57-66.

42 M. Fili pi a k, Biblia o cztowieku. Zarys antropologii biblijnej Starego Testamentu, Lublin 1979, s. 55; por. F. H. Me yenfeld t, Het hart (Leb Lebab) in het Oude Testament, Leyde 1960, s. 49-58; W. B a u m gart el, Leb, lebab im Altem Testament, ThWNT III, s. 609-611; H. W. Wolff, Antropologie des Alten Testaments, München 1973, s. 65-95. 
testanccy (np. E. Kautzsch ${ }^{43}$, P. Volz ${ }^{44}$ ) byli zdania, że Jeremiasz potępił tego rodzaju kult Jahwe i dlatego nazwano go „najostrzejszym przeciwnikiem wszelkiego kultu" 45 . Tymczasem, podobnie jak i inni prorocy, nie zwalczał kultu jako takiego $(14,12 ; 17,26)$. Jako członek rodziny kapłańskiej zapewne mial szacunek dla ofiar, wymienia ich rodzaje i zapowiada je w czasach mesjańskich $(31,14 ; 33,18)$. Nawiązując do poprzedników (Am 5,21 n; Oz 6,6; Iz 1,11 n; Mi 6,6-8), Jeremiasz zwalcza tylko czysto zewnętrzny kult, ofiary bez ducha $(7,21-23 ; 11,15 ; 14,12)$, ale w sposób szczególnie mocny ${ }^{46}$. Ofiara ma być zewnętrznym znakiem wewnętrznej więzi z Bogiem, dlatego ofiary, nawet najkosztowniejsze, sprowadzane aż z dalekiej Saby, są nieprzyjemne dla Boga, jeśli człowiek jest daleki Jemu, trwa w grzechach $(11,15)$. Nic nie znaczą także: zabobonna wiara w świątynię $(7,4)$, która stała się jaskinią zbójców $(7,11)$, posty $(14,12)$, czy obrzezanie $(4,4 ; 9,24 ; 24,25)$ bez zaprzestania życia grzesznego $(7,5 \mathrm{n} ; 18,8 ; 23,14 ; 44,4)$, zejście ze złej drogi $(15,7 ; 18,11 ; 23,22$; $25,5 ; 26,3 ; 35,15 ; 36,7)$, gruntownego wykorzenienia zła $(4,3)$. Kult nigdy nie zastąpi życia według przykazań Jahwe ${ }^{47}$. Może tylko podkreślać wierność Bogu.

Nawrócenie u Jeremiasza ma charakter uniwersalistyczny, a zarazem osobisty. Jeremiasz, podobnie jak poprzednicy zabiegał o nawrócenie całego narodu; choć niewątpliwie zwraca uwagę przede wszystkim na Judejczyków $(7,1$; $25,1 ; 26,2)$, na czele z mieszkańcami stolicy $(4,14 ; 8,5 ; 15,5)$, nieobcy jest mu los mieszkańców byłego Królestwa Północnego, którzy przeżywają tragedię swojej ojczyzny $(3,12)$. W czasach mesjańskich Jeremiasz przewiduje nawrócenie innych narodów: „Do Ciebie przyjdą narody z krańców ziemi i powiedzą: Przodkowie nasi odziedziczyli tylko fałsz, nicość pozbawioną jakiejkolwiek mocy! Czy może człowiek tworzyć sobie bogów? To przecież wcale nie są bogowie! Dlatego też pokażę im, tym razem dam im poznać moją rękę i moją potęgę; i zrozumieją, że moje imię to Jahwe"! (16,19—21; por. 3,17; 12,14-16).

Prorok zdawał sobie sprawę, że jeżeli nawrócenie ma objąć także wnętrze człowieka, to musi mieć charakter indywidualny; poprawa życia musi być sprawą osobistą każdej jednostki Narodu Wybranego. To personalistyczne ujęcie nawrócenia odpowiada również wysoce personalistycznemu zrozumieniu grzechu. Grzech dla Jeremiasza nie jest bowiem jakąś nieosobową, obiektywną winą, lecz polega na odpowiedzialnym czynie - wypowiedzeniu Bogu posłuszeństwa i zerwaniu serdecznych więzów z Nim, „opuszczeniu Jahwe $(1,16$; $2,13 ; 17,19 ; 5,7.19)$, niewierności Bogu Przymierza $(3,8 ; 11,13)$. Grzeszne postępowanie jest wyrazem niewdzięczności, braku zaufania i nieposłuszeństwa

${ }^{43}$ Biblische Theologie des Alten Testaments, Tübingen 1911, s. 236.

${ }_{44}$ P. Volz, Der Prophet Jeremia (KAT 10), Tübingen $1930^{3}$, s. 101-104.

45 Tamże, s. 104.

${ }^{46}$ S. Ła ch, Rozwój ofiar w religii starotestamentowej, Poznań 1970, s. 42.

${ }^{47}$ A. Geli n, Jérémie, Paris 1952, zwł. rozdz. IV: Le procès des institutions. 
Izraela w stosunku do Boga. Dlatego też w wezwaniach do nawrócenia z późniejszych okresów działalności często pada słowo „każdy”; „Zawróćcie więc każdy ('îš) ze swej złej drogi"' (18,11; por. 25,$5 ; 26,3 ; 35,15 ; 36,3)$. Inaczej próba nawrócenia narodu zakończy się takim samym fiaskiem jak reforma Jozjasza. U Jeremiasza ten osobowy charakter nawrócenia jest dopiero delikatnie zarysowany. Personalistyczny aspekt grzechu i nawrócenia rozwinie i pogłębi prorok Ezechiel ${ }^{48}$.

Powyższe dane upoważniają nas do stwierdzenia, że prorok Jeremiasz jako pierwszy stworzył dojrzałą koncepcję nawrócenia i przez to odegrał zasadniczą rolę w rozwoju tej starotestamentalnej idei. Nadał jej bowiem postać zbliżoną do szczytu nowotestamentalnego ujęcia przez to, że:

1. Podkreślił jego wewnętrzny i osobisty, a zarazem uniwersalny charakter.

2. W aspekcie negatywnym ukazał nawrócenie jako zaniechanie grzechów, a zwłaszcza bałwochwalstwa i krzywd społecznych.

3. Wyraźnie związał nawrócenie w aspekcie pozytywnym z ideą Przymierza, które jest „osią religii Izraela, jej siłą napędową"49.

Dla proroka Jeremiasza nawrócenie w ujęciu pozytywnym jest powrotem do coraz serdeczniejszego obcowania z Bogiem poprzez ustawiczne aktualizowanie Przymierza, coraz wierniejszym zachowywaniem Prawa.

\section{NAWRÓCENIE JAKO DZIEŁO BOŻEJ MIŁOŚCI}

Prorok Jeremiasz, zwłaszcza pod koniec swej działalności był wyraźnie bardziej niż jego poprzednicy zdumiony niemal fizyczną niemocą człowieka żyjącego w grzesznym nałogu. Trafnie wyrazil to A. Hulsbosch ${ }^{50}$ w słowach: „Żaden ze starotestamentalnych proroków i redaktorów nie mówi tak dużo o nawróceniu jak Jeremiasz, lecz chyba także nikt nie był przekonany o niemożliwości nawrócenia jak właśnie on". Izraelici stali więc więźniami grzechu; grzech niejako stał się ich drugą naturą: „Czy Kuszyta może zmienić swoją skórę, a lampart swoje pręgi? Podobnie wy — przyzwyczajeni do zła — czy możecie czynić dobrze? $(13,23)^{51}$. Podobnie jak czarny Kuszyta nie może zmienić koloru swej skóry, czy lampart swej pręgowatej sierści, tak Izraelici nie mogą się nawrócić w aktualnym stanie upadku religijno-moralnego. Przy tym należy jednak pamiętać o istotnej różnicy między grzesznością ludu a skórą Etiopczyka. Etiopczyk urodził się w swej skórze, a pantera w swoim futrze i dlatego nie

$48 \mathrm{~J}$. D el orme, Conversion et pardon selon le prophète Ezechiel [w:] Mémorial J. Chaine, Lyon 1950, s. 115-144; M. F. La can, jw. (przyp. 40), s. 18 n; J. Giblet, jw. (przyp. 29), s. 90; H. Gross, jw. (przyp. 4), s. 164-166.

49 J. K u dasi e w i cz, Historia i teologia Przymierza, [w:] Materiaty pomocnicze do wyktadów $z$ biblistyki, I. Lublin 1975, s. 147.

50 A. Huls b os ch, Die Bekehrung im Zeugniss der Bibel, Salzburg 1967, s. 18.

${ }^{51}$ Por. A. Gelin, jw. (przyp. 47), s. 130; J. Hom er ski, jw. (przyp. 7), s. 38. 
odpowiedzialni za swoje cechy. Człowiekowi jednak nie zostało włożone do kołyski zło i grzech, lecz sam je nabył i tak się do nich przyzwyczaił, że stały się jego drugą naturą. Grzech tak przesycił osobowość Izraelitów, że Jeremiasz nie zawahał się stwierdzić: „Grzech Judy jest zapisany żelaznym rylcem, wyryty diamentowym ostrzem na tablicy ich serc" $(17,1)$. Naród Wybrany jest tak zapamiętały w grzesznym postępowaniu, jak koń rozpędzony do szaleństwa w walce $(8,6)$. Izrael jest jakby chory na „raka grzechowego" (por. 8,22) ${ }^{52}$. Ratunek jest więc niestety niemożliwy i co najstraszniejsze - według duchowej diagnozy Jeremiasza - tą straszną chorobą jest objęty cały Naród Wybrany: „wszyscy zgrzeszyliście przeciw mnie” (2,29; por. 5,1.3.8.11; 6,13.27 n; 8,6.10; $9,1-5 ; 11,8 ; 16,12 ; 18,12$ ).

Praktyczna niemożliwość powrotu Izraela do Boga jest skutkiem „zatwardziałości serca" $(3,17 ; 7,24 ; 9,13 ; 11,8 ; 13,10 ; 16,12 ; 18,12 ; 23,17)$; podobną ideę wyrażają: „nieobrzezane serca” $(4,4)$, „twardość karku” $(7,26 ; 17,23$; $19,15)$ i „nieobrzezanie uszu; $(6,10)$, czyli brak podatności na nawrócenie, znieczulica na Boga, zasklepianie się, otępienie duchowe zapowiedziane przez proroka Izajasza $(6,10)$. Taka postawa człowieka jest wynikiem długotrwałego procesu odejścia od Boga ${ }^{53}$. Izrael jest do tego stopnia oszołomiony grzechami, że „mając oczy nie widzi, mając uszy nie słyszy” $(5,21)$, nie docierają do niego słowa Boga $(7,26 ; 11,8 ; 13,10 ; 16,12 ; 18,18 ; 19,15 ; 26,3.5 .13 ; 35,15)$, na co wielokrotnie skarży się Jeremiasz. Izraelici w swym braku rozsądku i rozwagi, w swym zaślepieniu $(4,22 ; 5,21)$, nie potrafią dostrzec potęgi Boga, obserwując żywioły świata w całym swym ogromie $(5,22)$, nie rozumieją kar poprawczych $(5,3)$, którymi często są klęski żywiołowe (np. suszy 3,$3 ; 14,1-6)$ i dlatego nie potrafią opamiętać się, nawet w obliczu strasznych najazdów nieprzyjacielskich niosących spustoszenie kraju $(4,13-18 ; 5,15-17 ; 8,14-17 ; 12,7-$ $13 \mathrm{i} \mathrm{cz})$ i zagładę $(5,19 ; 7,15 ; 17,4 \mathrm{i} \mathrm{cz})$ : więcej, Izraelici nie mogą się zdobyć na decyzję nawrócenia mimo ponawianej zapowiedzi niewoli i zburzenia Jerozolimy $(5,19 ; 7,15 ; 17,4 \mathrm{i} c z)$. Izrael jest więc tak hermetycznie zamknięty w swym grzechu, że nawet nie jest zdolny zdobyć się na to, by podjąć inicjatywę nawrócenia, więcej, nie jest zdolny zrobić nawet wstępnych kroków w tym procesie: „Zawstydzą się (może), ponieważ wszyscy postępowali obrzydliwie? Ależ bynajmniej! Wstydem się nie przejmują, nawet nie potrafią się zarumienić" $(6,15)$. Wiersz ten jest powtórzony w 8,12 .

Inicjatywa nawrócenia musi wyjść od samego Boga. Bóg zaś swoje wezwanie do pokuty kieruje przez słowo proroka. Tak więc już sam impuls nawrócenia jest dziełem łaski. Jest zatem niczym niezasłużonym darem miłosierdzia Bożego. Nawet po klęsce narodowej, która musiała być wstrząsem dla Judejczyków, Jeremiasz musi po przypomnieniu grzechów osobistych narodu

${ }^{52}$ M. Pete r, Wykład Pisma świętego Starego Testamentu, Poznań 1970, s. 693.

53 X. Lé on-Dufour, Endurcissment, VThB ${ }^{2}$, s. 347-349; F. Hesse, Das Verstockungsproblem im AT (BZAW 74), Berlin 1955. 
stwierdzić, że nie zrobili nawet kroku na drodze nawrócenia: „Aż do dnia dzisiejszego nie okazują skruchy ani bojaźni i nie przestrzegają mojego Prawa i moich przykazań $(44,10)$. Jest to ostatni chronologicznie dokument działalności proroka Jeremiasza. Ponieważ wszystkie usiłowania Boga, których celem było spowodowanie nawrócenia Izraelitów, zostały odrzucone właśnie przez nich, Bóg musiał na drodze do nawrócenia postawić to, co stało się dla Izraelitów straszliwą tragedią - klęskę i niewolę babilońską. Tę smutną konieczność zapowiedział prorok Ozeasz stwierdzając, że przed nawróceniem się Izrael musi powrócić do Egiptu $(11,5)$, czyli na nowo przeżyć koszmar niewoli. Miłość Jahwe jest jednak ,potężniejsza niż zdrada" ${ }^{4}$ i dlatego Izrael nie zostanie ostatecznie odrzucony przez Boga. Niewola stanie się nie zastąpionym klimatem uświadomienia sobie winy, przeżycia szczerego żalu i zdobycia się na zdecydowaną decyzję powrotu do Boga. Zasadnicza zmiana postępowania Izraelitów, wskutek konieczności gruntownej przemiany duchowej, okazała się nieosiągalną siłami ludzkimi. Tego może dokonać tylko ingerencja Boga w życie moralne człowieka, ponieważ chodzi tu o odnowienie serca, czyli o nowe stworzenie. W wyniku działania Bożego musi dojść do przekształcenia człowieka od wewnątrz, czyli do stworzenia nowych uzdolnień duchowych: „Dam im serce (zdolne) Mnie poznać, że to Ja jestem Jahwe. Będą moim ludem, a ja będę ich Bogiem, zatem całym sercem nawrócą się do Mnie" $(24,7)$.

Na czym będzie polegać to nowe stworzenie narodu? Jakby bariera oddzielają naród od Boga liczne grzechy. Wszystkie zaś zabiegi człowieka w celu oczyszczenia się z grzechu są bezskuteczne: „Choćbyś się obmyła ługiem sodowym i wiele ługu drzewnego zużyła, twoja wina jak skaza pozostanie wobec Mnie - wyrokuje Pan, Jahwe" (2,22; por. 17,1). Dlatego Bóg kształtując nowe wnętrze czlowieka przebaczy mu grzechy: „Wszyscy poznają Mnie od najmniejszego (z nich) do największego - głosi Jahwe. Przebaczę bowiem ich winy i grzechów ich już pamiętać nie będę" $(31,34$ b; por. 30,$17 ; 33,8)$. Ponadto Bóg obdarzy człowieka jakby instynktem religijności. Na czym on będzie polegał? Otóż serce ludzkie uczyni Bóg do tego stopnia pojętnym i chłonnym na Jego sprawy, że zbędnym staną się pouczenia ludzkie: „Nie będą się już pouczać wzajemnie jeden drugiego” mówiąc: „Poznajcie Jahwe” (31,34 a). Nowe serce człowieka będzie wyposażone w zdolność poznania Jahwe, czyli skłonność do przywiązania się do Niego przez wiarę i miłość. Serce człowieka będzie doświadczało nowej orientacji, która skieruje go całkowicie na wskazania Jahwe. Dzięki temu będzie możliwa wierność Przymierzu z Jahwe. Wiara i miłość nowego serca będą bowiem pobudzać do wypełniania Prawa Przymierza i wzmacniać w tym poprzez wyzwalanie coraz to nowych sił. Wypełnianie Prawa stanie się nieodpartym dążeniem serc. Wyposażenie człowieka w dar spon-

${ }^{54}$ Encyklika Ojca Swiętego Jana Pawta II o Bożym mitosierdziu Dives in miscericordia, Tekst i Komentarz. Kraków 1981, 14 odn. 52. 
tanicznego wypełniania Prawa Przymierza wyraził Prorok przy pomocy słów: „Natomiast takie będzie Przymierze, które zawrę z Domem Izraela po dniach owych - głosi Jahwe: Umieszczę Prawo moje w ich wnętrzu i wypiszę na ich sercu: I będę im Bogiem, a oni będą Mi narodem"55. Nawrócenia Izraelitów dokona Jahwe swoją mocą, ale nie bez ich współdziałania: „Spraw, bym powrócił , a nawrócę się, bo jesteś Jahwe, moim Bogiem" $(31,18)$. Wszystko tutaj zależy od Boga, a jednak człowiek musi współdziałać z Bożą łaską. Człowiek musi się dobrowolnie otworzyć na stwórczy dar Boga i prosić Go w pokornej modlitwie o ten dar. Chociaż Bóg nie zrobi wszystkiego, potrzebne jest zaangażowanie człowieka, to jednak udział Boga w mającym się dokonać nawróceniu będzie wyraźnie dominujący. Prorok Jeremiasz przekonał się o konieczności dominującego udziału Boga w odnowieniu człowieka przez osobiste doświadczenie prorockie. Przeżywając głęboką wewnętrzną udrękę z powodu szyderstw ze słowa Jahwe, a zarazem kryzys swej misji prorockiej, modli się słowami zaczerpniętymi z modlitw Psalmów przebłagalnych wierząc, że jego kryzys duchowy może uleczyć jedynie Bóg: „Uzdrów mnie, Jahwe, a będę zdrowym; wbrew mnie, a będę zbawiony! Ty bowiem jesteś moją chlubą!" $(17,14)^{56}$. Nawrócenie Izraelitów dokona się bez jakichkolwiek ludzkich zasług; będzie zupełnie darmowym darem Boga, będzie dziełem hojnej wszechmocy i dobroci, czyli miłości Bożej ${ }^{57}$. Prorok Jeremiasz do tego stopnia zgłębił udział miłości Bożej w ludzkim nawróceniu, że A. Hulsbosch mógł postawić stwierdzenie: „Księga Jeremiasza wprowadza nas w tajemnicę człowieka, a zarazem w tajemnicę Bożej łaski" 58 .

Aby zrozumieć wkład Jeremiasza w rozwój idei nawrócenia jako dzieła Bożej miłości, należy przypomnieć stan tej idei u poprzedników. Otóż ten problem delikatnie dotknęli prorocy Ozeasz i Sofoniasz: Ozeasz zapowiadając przyszłe nawrócenie Izraela-Oblubienicy wkłada w usta Jahwe słowa: „Usunę z jej ust imiona Baalów i już nie będzie wymawiać ich imion” $(2,19)$; „Uleczę ich niewierność i umiłuję z serca" $(14,5)$. Bóg więc uzdrowi Izraela z odstępstwa od Niego ku bożkom jako ze śmiertelnej choroby. Natomiast prorok Sofoniasz wyraził akcję Boga w zapowiadanym nawróceniu następująco: „Usunę bowiem wtedy spośród ciebie pysznych samochwalców twoich i nie będziesz się więcej wywyższać na świętej mej górze. I zostawię pośród ciebie lud pokorny i biedny, a szukać będą schronienia w imieniu Jahwe" (3,11 n). Szczęśliwą przyszłością obdarzy więc Bóg nie pewnych siebie bogaczy, którzy swoim celem życia czynią zdobywanie majątku, lecz pokornych i ubogich, którzy całą

${ }^{55} \mathrm{U}$. Deve scovi, Annotazioni sulla dotrina de Geremia circa la nuova alleanza, R Bib.It $8(1960)$, s. 117-120.

56 C. Ha u r et, Note d'exégèse, Jér 17,14; Sana me Domine et sanabor, RevScR 36(1962) s. $174-184$.

${ }^{57}$ M. F. Lacan, jw. (przyp. 40), s. 16.

58 Jw. (przyp. 50), s. 18. 
nadzieję pokładają w Bogu. Wypowiedzi te tylko w sposób bardzo ogólny sugerują jakiś udział Boga w nawróceniu Izraelitów. Na tym tle widać, jak bardzo zgłębił prorok Jeremiasz udział Boga w wewnętrznej przemianie Izraela a zarazem szczegółowo analizuje postawy ludzi wracających do Boga. Te analizy ludzkich postaw pozwoliły Jeremiaszowi skonkretyzować warunki, jakie muszą spełnić Izraelici wracający do Boga. Prorok Jeremiasz szczególnie wyakcentował sprawę przyjęcia orędzia prorockiego przez Izraelitów jako głosu Boga Przymierza. Przyjęcie słowa prorockiego umożliwi Izraelitom zrozumienie okrucieństwa ich grzesznego postępowania w stosunku do Boga. Dzięki wsłuchaniu się w słowa proroka, Izraelici na nowo mają odkryć urzekającą miłość Jahwe, którą przyciągnie On Izraelitów do Siebie. Wtedy też zrozumieją potęgę Boga, a zarazem jego bezgraniczne miłosierdzie, dzięki któremu jest On wciąż gotowy przebaczyć Izraelowi dotychczasowe grzechy. Wtedy Izraelici przeżyją głęboki wstyd i żal z powodu tak grzesznego postępowania, które wyznają Bogu. Wstyd, żal, wyznawanie win są szczególnie mocno wyakcentowane przez proroka $\mathrm{z}$ Anatot.

Wkład Jeremiasza jest szczególnie widoczny w określeniu istoty nawrócenia, którą ujmuje jako aktualizację Przymierza. Ta aktualizacja Przymierza musi mieć charakter osobowy, a zarazem zdecydowanie wewnętrzny. Prorok Jeremiasz ponadto jako pierwszy dostrzegł, że tylko Bóg może dokonać ostatecznej odnowy Izraela. Nawrócenie musi być szczególnym darem Bożym, ponieważ niewystarczającymi okazały się kolejne próby aktualizacji Przymierza dokonane przez królów (Ezechiasz, Jozjasz). Bezskutecznym okazały się także nawoływania proroków do nawrócenia. W Nowym Przymierzu na skutek miłosiernej interwencji Boga zaistnieje bardziej wewnętrzny związek między Bogiem a jego ludem. Prawo zaś będą wypełniali ludzie dobrowolnie, z wewnętrznej potrzeby, ponieważ serce stanie się jakby tablicą Prawa. Dokona tego Bóg poprzez obdarzenie ludzi swoistym uzdolnieniem religijnym. Tak dojrzała idea nawrócenia proroka Jeremiasza wprowadza nas w Chrystusowe orędzie nawrócenia, rozpoczynające się od wezwania do metanoi.

Dotychczasowe rozważania upoważniają nas do stwierdzenia, iż proroka Jeremiasza można nazwać ojcem dojrzałej idei nawrócenia jako dzieła Bożej miłości. Wyraża się ona w następujących tezach:

1. Samo podjęcie decyzji nawrócenia przez Izraelitów może być jedynie wynikiem Bożej ingerencji.

2. Prawdziwe nawrócenie Izraela będzie polegać na przekształceniu wnętrza człowieka. Dokona tego Bóg, ale nie bez udziału człowieka. 
3. Na nowe stworzenie wnętrza człowieka złoży się oczyszczenie z grzechów i obdarzenie instynktem religijnym, który będzie polegał na szczególnym uzdolnieniu duchowym. Dzięki niemu Izrael będzie, jakby pod działaniem nieodpartej siły, układał swoje życie zgodnie z Prawem Przymierza.

4. Udział Boga w nawróceniu Izraela będzie więc dominujący, a zarazem nie uprzedzony żadnymi ludzkimi zasługami.

Analiza teologiczna pozwala nam wyciągnąć zasadniczy wniosek, że prorok Jeremiasz jako pierwszy stworzył dojrzałą koncepcję nawrócenia i przez to wniósł ogromny wkład w podprowadzenie biblijnej idei nawrócenia do nowotestamentalnego szczytu jej rozwoju

Trzeba podkreślić również to, że idea nawrócenia u proroka z Anatot nie ma nic wspólnego z pesymizmem, pomimo wzrastającego $\mathrm{w}$ nim przekonania o powszechności i dogłębności zepsucia życia moralno-religijnego Izraelitów oraz konieczności głoszenia sądu Bożego. Zbawczy optymizm zachował prorok, mimo zatwardziałości grzesznych serc Izraelitów, nawet podczas nadchodzącej i dokonującej się tragedii Królestwa Judzkiego głosząc, że droga powrotu do Boga jest nadal otwarta. Prorok Jeremiasz z wielkim artyzmem literackim przekonuje Izraelitów o konieczności powrotu do Jahwe.

\section{THEOLOGIE DER BFKFHRING IM BLCH JEREMIAS}

\section{Zusammenfassung}

Der Prophet Jeremias entwart als erster eine ausgereifte Bekehrungskonzeption und hat dadurch den größten Anteil an der Entwicklung der Bekehrungsidee im Alten Testament. Deshalb gibt man ihm gerechterweise den Titel „Doktor der Bekehrung”.

Man darf davon ausgehen, daß3 die Bekehrung des Propheten aus Anathoth mit Pessimismus nichts gemeinsam hat, obwohl in ihm die Überzeugung hinsichtlich des allgemeinen und tiefgreifenden Verfalls des moralischen und religiösen Lebens der Israeliten ihr gutes Gewicht hatte und er die unbedingte Notwendigkeit empland, vom Gottes gericht predigen zu müssen. Seinen rettenden Optimismus behielt der Prophet trotz der Verhärtung der sündigen Herzen der Israeliten bei und predigte sogar während der sich ankündigenden und später stattfindenden Tragödie des Königgreiches der Juden, dalß die Rückkehr zu Gott jederzeit möglich sei. Der Prophet Jeremias bringt die Israeliten mit großer literarischer Kunstfertigkeit zu der Erkenntnis, zu Jahwe zurückkehren, und analysiert in allen Einzelheiten das Verhalten eben der Menschen, die so zu Gott zutanden. Die Verhaltensanalyse als solche aber ermöglichte es Jeremias, die Bedingungen zu konkretis ieren, welche die Israeliten erfüllen müssen, um zu Gott zurückkehren zu können. Der Prophet akzentuiert dabei besonders das Akzeptieren der prophetischen Botschaft durch die Israeliten gleichsam als Stimme Gottes des ewigen Bundes. Die Annahme der Worte des Propheten ermöglicht den Israeliten, die Grausamkeit ihres sündigen Verhaltens Gott gegenüber zu verstehen. Auf Grund des tieferen Verständnisses der Worte des Propheten sollen die Israeliten erneut 
die überwähtigende Liebe entdecken, durch welche Jahwe die Israeliten für sich gewinnt. Erst jetzt verstehen sie die Macht Gottes und gleichzeitig sein grenzenloses Erbarmen, auf Grund dessen er jederzeit bereit ist, Israel seine bisherigen Verfehlungen und Sünden zu verzeihen. Und erst jetzt auch empfinden die Israeliten eine große Scham und Reue wegen ihres sündigen Verhaltens Gott gegenüber. Die Notwendigkeit dieser Voraussetzungen betonte der Prophet aus Anathoth oftmals.

Der Beitrag des Jeremias ist besonders ersichtlich aus der Definition des Wesens der Bekehrung, welche er als Aktualisierung des Ewigen Bundes durch ständige getreue Bewahrung des Rechts erfasst. Die Aktualisierung des Ewigen Bundes muß einerseits einen persönlichen, andererseits aber auch konkret geistigen Charakter haben. Der Prophet betonte dabei als erster, daß nur Gott die endgültige Erneuerung Israels durchführen könne. Die Bekehrung muß eine besondere Gabe Gottes sein, da durch Könige (Ezechias, Josua) vorgenommene vorhergegangene Versuche, den Ewigen Bund zu aktualisieren, sich als erfolglos erwiesen. Ebenfalls ohne Erfolg blieben aufrufe zur Bekehrung durch andere Propheten.

Im Neuen Bund tritt auf Grund des Barmherzigen Eingreifens Gottes eine tiefere Verbindung zwischen Gott und seinem Volk ein. Das Recht hingegen sollen die Menschen freiwillig und aus inneren Überzeugung heraus erfüllen, da das Herz wie zu einer ehernen Lade des Rechts wird. Gott ereicht dies, indem er den Menschen eine spezifische Gabe zur Religiösität gibt, welche sie dankbar, gleichsam in Folge einer unwiderstehlichen Kraft, ihr Leben in Übereinstimmung mit dem Recht des Bundes gestalten laßt. Der Anteil Gottes bei der Bekehrung Israels wird also dominierend und dabei durch keinerlei menschliche Verdienste antizipiert. So reifte denn die Bekehrungsidee des Propheten Jeremias und führt uns zu der Bekehrungsidee von Christus hin, welche mit dem Ruf zur Metanoia begann. 